cents; the cost for economics journals was $\mathbf{1 0 . 6 0}$ and that for neuroscience journals 13.83.

But in terms of cost-effectiveness, as measured by the ratio of cost to impact, neuroscience, at 7.7, emerged better than physics journals (11.5) and much better than economics publications (29.8); a lower ratio denotes better costeffectiveness.

Ten years after the Barschall study, not-for-profit publishers again emerged in general as a better bargain in terms of cost/impact than commercial publishers. Commercial journals scored worse than not-for-profit journals in all three disciplines: 14.61 versus 8.23 in physics, 42.62 versus 11.55 in economics and 8.69 versus 0.64 in neuroscience.

Nature was not included in the study. But data also gathered by Wisconsin library on the use of thousands of its journals show Nature to be one of the most cost-effective journals in terms of 'cost per use' (http://www.wisc.edu/ wendt/journals/costben/stee8.pdf).

Nature's average cost-per-use was 62 cents last year, and as low as 18 cents at one library. In contrast, over 600 journals had cost-per-uses of more than $\$ 45$, with some as high as $\$ 700$. Declan Butler

\title{
Bombing of embassy bolsters support for science in China...
}

Beijing

The efforts of China's research community to argue for policies that favour technological innovation have received a boost from an unexpected quarter - NATO's bombing of the Chinese embassy in Belgrade, Yugoslavia, last May.

The bombing appears to have led to a greater recognition of the importance of science and technology by the Chinese people, including top government officials. The development of cutting-edge technologies is regarded as crucial to national security. Privately, scientists are saying that the bombing has stimulated the government into increasing its attention to science and technology.

Last week, 23 scientists were awarded gold medals — some posthumously — for their contributions to the development of China's first nuclear weapons, missiles and first satellite. The medals were presented by president Jiang Zemin at a ceremony in the Great Hall of the People in Beijing.

The ceremony was presided over by $\mathrm{Li}$ Peng, chairman of the National People's
Congress. Jiang and prime minister Zhu Rongji addressed the meeting, speaking highly of the achievements of the scientists. All Politburo members and top government officials were present.

"Without national defence, there will be no nation; without a national defence industry, there will be no national defence," said Zhu recently. A statement issued by the government says: "Without grasping state-ofthe-art technologies, we will be bullied."

In the weeks after the bombing, discussions in the science community emphasized the achievements of Chinese scientists in developing the nation's first atomic and hydrogen bombs, and missiles, in the 1960s. Participants stressed the need for China to develop its own high technologies so that the United States could no longer bully it.

The bombing appears to have increased the respect given to scientists. Leading scientists from military research organizations have been invited to talk on television about the technologies used by NATO in its bombing of the embassy.

Tian Xuewen

\section{... as government sets sights on an 'innovation economy'}

\section{Beijing}

China has confirmed its commitment to encouraging closer links between research institutions and industry, and has instructed all government departments to draw up plans for helping to create an innovationbased economy.

Political bodies have called for greater rewards for scientists and engineers responsible for successful innovations. They will now be allowed to hold shares in companies that exploit their inventions commercially.

The endorsement of the importance of high technology to economic prosperity came during a four-day meeting at the end of last month in Beijing, chaired by prime minister Zhu Rongji and attended by president Jiang Zemin and members of the Politburo, the top authority in China's power hierarchy.

The conference was held to increase awareness among party and government officials of the need to boost technological innovation. A statement issued by the party central committee and the state council before the meeting lists various steps to achieve this. These include accelerating the technological upgrading of traditional industries and increasing the knowledge content of the service sector.

Following the meeting, all major govern-

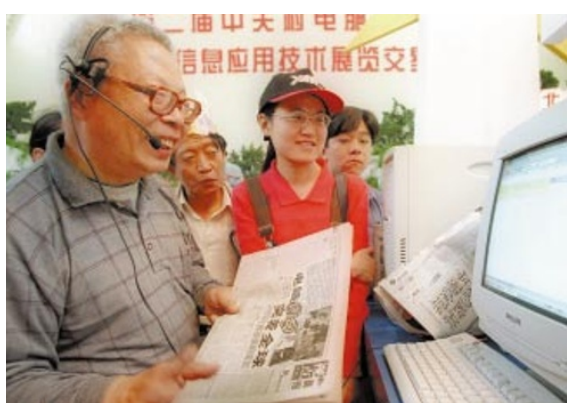

Great leap forward: the Chinese public is being encouraged to embrace high technology.

ment agencies are discussing how to put these principles into practice. "We will come out with an action plan very soon," says a spokesman for the science ministry.

Science minister Zhu Lilan said the government wanted industries to become the main force in promoting innovation, and that mechanisms should be set up for using venture capital to help achieve this.

$\mathrm{Xu}$ Guanhua, vice-minister of the science ministry, said in a television interview that there was inadequate interaction between research institutions and industry in China. As a result, scientific findings were often left unexploited for years. This situation will improve in the future, said $\mathrm{Xu}$, as technologi- cal brokers will be given a greater role in bring ing research institutions and industry closer.

$\mathrm{Xu}$, an expert on remote sensing and former vice-president of the Chinese Academy of Sciences, also expressed concern about the low level of state support for research and development. In 1997, China's spending on research and development was only 0.64 per cent of its gross domestic product. In 1998, the total spending in China was less than the increase in spending alone in the United States over the previous year.

The Chinese Academy of Sciences, China's major research organization, was also due to produce an action plan, to be decided by a top-level meeting on 9 September. But no details have been released yet.

The academy was traditionally focused on basic science, but has been dedicating increasing efforts to applied science and industrial research in recent years. It was selected by the government a year ago to be a target for reform under the National Knowledge Innovation Campaign. More radical reforms of the academy are expected to follow from the conference.

Science parks and high-technology industrial development zones will attract more attention as a result of the conference, according to a paper from the science ministry. T. $\mathbf{x}$. 